\title{
Coastal change and hypoxia in the northern Gulf of Mexico: Part I
}

\author{
E.C. Krug \\ Illinois State Water Survey, 2204 Griffith Drive, Champaign, IL, USA 61820 \\ Email: ekrug@sws.uiuc.edu
}

\begin{abstract}
The Committee on Environment and Natural Resources (CENR) has identified the input of nutrient-rich water from the Mississippi/Atchafalaya River Basin (MARB) as the prime cause of hypoxia in the northern Gulf of Mexico and the prime means for its control. A Watershed Nutrient Task Force was formed to solve the hypoxia problem by managing the MARB catchment. However, the hypoxic zone is also experiencing massive physical, hydrological, chemical and biological changes associated with an immense river-switching and delta-building event that occurs here about once a millennium. Coastal change induced hypoxia in the northern Gulf of Mexico prior to European settlement. It is recommended that for further understanding and control of Gulf hypoxia the Watershed Nutrient Task Force adopt a truly holistic environmental approach which includes the full effects of this highly dynamic coastal area.
\end{abstract}

Keywords: Gulf of Mexico, hypoxia, geology, anoxia, nutrients, marine transgression, marine regression, dissolved oxygen

\section{Introduction}

Various environmental monitoring and research programmes have pointed to the occurrence of regional seasonal hypoxia in the northern Gulf of Mexico during and after the year of the great flood of 1973 on the Mississippi and Atchafalaya rivers (Fucik, 1974; Ragan et al., 1978; Bender et al., 1979; Oetking et al., 1979a,b; Bedinger et al., 1981; Harper et al., 1981; Gaston, 1985; Rossignol-Strick, 1985; Pokryfki and Randall, 1987). With summertime stratification providing a cap of warmer and less saline water, organic matter decay depleted dissolved oxygen (DO) in the underlying bottom water layer to $\leq 2 \mathrm{mg} \mathrm{L}^{-1}$ in that part of the Gulf of Mexico bounded by the curve of the Louisiana-Texas coast (Fig. 1). Such hypoxic DO values are lethal to many species of desirable aquatic and marine organisms. However, nutrientenriched riverine discharges can enhance fishery production on adjacent continental shelves, including the northern Gulf of Mexico (Riley, 1937; Liebman, 1940; Gunter, 1952; Caddy, 1993; Diaz and Solow, 1999; Grimes, 2001). Since 1985, the US government has supported a Gulf hypoxia monitoring programme; the officially-reported size of Gulf hypoxia is that measured during the programme's midsummer cruise.

Starting with the 1993 flood, the average annual extent of the hypoxic zone has increased drastically. For example, the area doubled from $8000-9000 \mathrm{~km}^{2}$ for $1985-92$ to 16 000-18 $000 \mathrm{~km}^{2}$ for 1993-1997 (Rabalais et al., 1997, 1999; CENR, 2000) and has continued to grow thereafter. For example, in 1999 hypoxia achieved a new record maximum size of $20000 \mathrm{~km}^{2}$ and this record was broken again in $2001\left(>20000 \mathrm{~km}^{2}\right)$ and in $2002\left(22000 \mathrm{~km}^{2}\right)$. Disturbances by multiple tropical storms and hurricanes during the 2003-2005 period created an environment unfavourable for hypoxia development (Louisiana Universities Marine Consortium, 2001, 2002, 2003, 2004, 2005; National Centers for Coastal Ocean Science, 2004; USGS, 2004; National Hurricane Center, 2006; Ocean Remote Sensing Group, 2006).

In response to the sharp and sustained increase in Gulf hypoxia, a federal interagency working group was formed. 


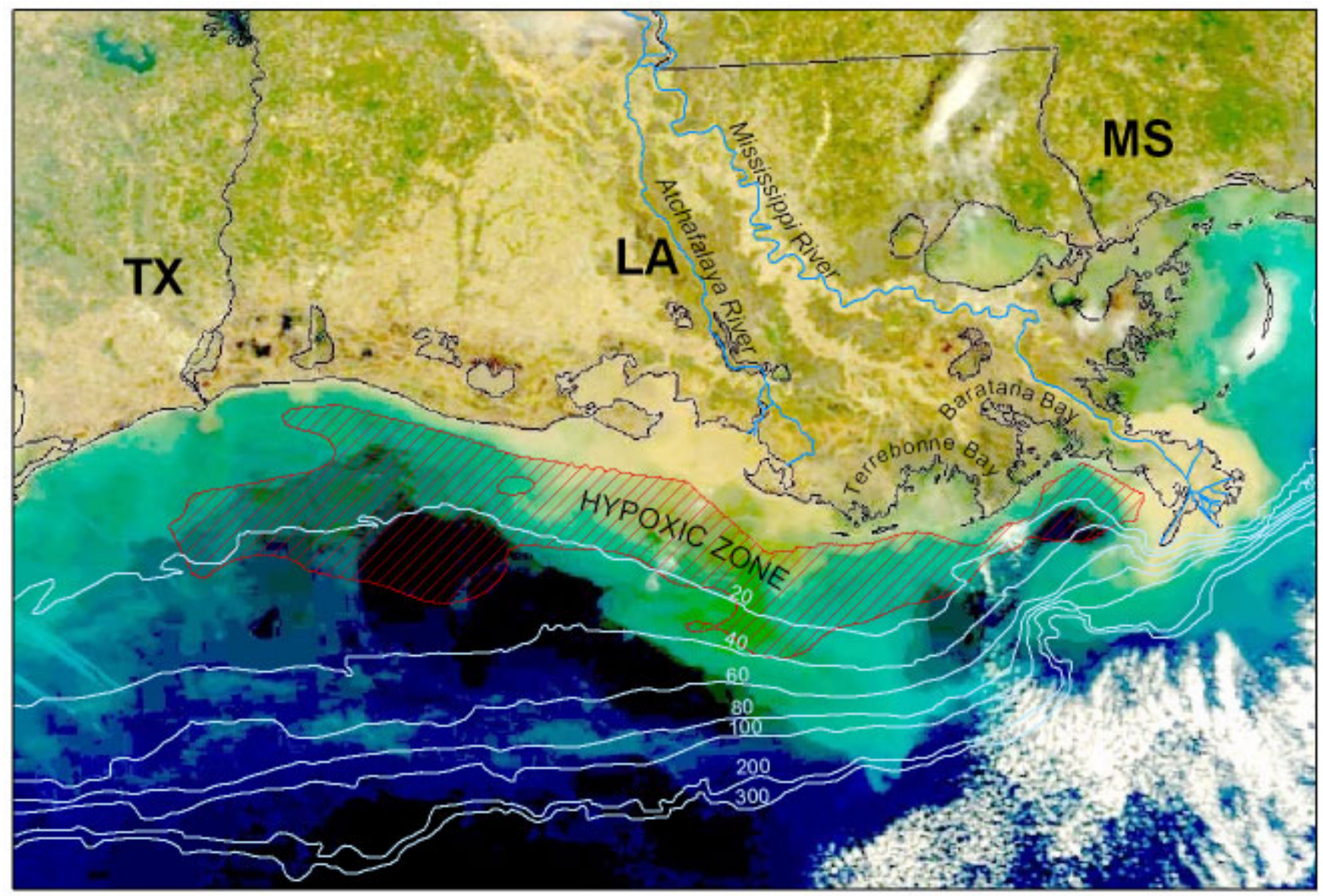

Fig. 1. The measured extent of hypoxia in 2002 (Louisiana Universities Marine Consortium, 2002) in the Northern Gulf of Mexico (Space Science and Engineering Center, 2002). Contour depths are in metres. See figure description in Appendix 1.

In 1995, the US National Science and Technology Council Committee on Environment and Natural Resources (CENR) published the report, "Setting a New Course for U.S. Coastal Ocean Science." The report, developed by consensus among federal science agencies, the university community and natural resource managers, recommended a comprehensive, integrated, systems approach to address the complexities associated with the degradation of coastal ocean quality, including hypoxia. This approach recognised the heterogeneous and highly dynamic nature of coastal environments and the need to address freshwater, suspended solids, terrestrial organic matter and land-use changes, as well as dissolved nutrient discharges to coastal waters (CENR, 1995). Since then, a more circumscribed approach to Gulf hypoxia has been adhered to. The Gulf of Mexico Program (administered by the USEPA) promoted controlling hypoxia by reducing the flow of nutrients from the Mississippi/Atchafalaya River Basin (MARB). It is a 'no regrets' approach to implementing fertiliser- and land-use controls in the MARB (Gulf of Mexico Program, 1996a,b,c). Or, to quote director Giattina in his review of the programme "Whether or not they solve the hypoxia issue in the long run, they'll benefit local landowners" (Showstack, 1997, p. 478).

In 1997, representatives from states and tribes were added to the above-mentioned federal interagency working group to form the Mississippi River/Gulf of Mexico Watershed Nutrient Task Force (Watershed Nutrient Task Force). In its first meeting:

"Mr Perciasepe [USEPA] welcomed the state and tribal representatives to the Task Force and set the goal of the Meeting as getting everyone to a common state of information about the problem of nutrients and hypoxia in the Gulf of Mexico..... He stressed a kind of strategy in which everyone works together to move ahead with nutrient control solutions and not wait until the problem is too large to handle." (Mississippi River/Gulf of Mexico Watershed Nutrient Task Force, 1997, pp. 1-2).

In March 1998, CENR put out the Gulf of Mexico Hypoxia Assessment Plan for the Watershed Nutrient Task Force. The Plan announced six topic areas and identified leaders for each of the topic report teams; it also announced that the six topic areas will be addressed in the context of MARB nutrient loadings to the Gulf of Mexico. 
In December 1998, just nine months later, the six topic reports were completed and sent out for review. They were accompanied by a covering letter which stated: "These [six topic] reports will form the basis for an Integrated Assessment, delivered through the White House CENR to the Mississippi River/Gulf of Mexico Watershed Nutrient Task Force, that analyses policy options for nutrient management for the Mississippi River watershed and northern Gulf of Mexico." (Scavia, 1998). Except for climate change, factors other than inputs of MARB nutrient-enriched water were dismissed (principally in the Topic 1 Report) as being incapable of producing annual, regional hypoxia in the northern Gulf of Mexico. Global warming was considered to be a potential secondary factor capable of increasing hypoxia by increasing the runoff of water and nutrients from the MARB, as demonstrated by peaks of oxygen stress correlating to flood years, and by increasing surface water temperatures of coastal waters (Rabalais et al., 1999). The Topic 1 Report stated that sediment samples collected offshore immediately west of the Mississippi River, offshore Barataria and Terrebonne estuaries and the Mississippi (Fig. 1), showed a gradual increase in oxygen stress starting in the early 1800 s with a rapid increase beginning in the mid-20th century; the former was credited to release of native soil nutrients by European settlement of the MARB and the latter was attributed to the steep increase in MARB fertiliser use (Rabalais et al., 1999, pp. 93-108).

Subsequent to the publication of the six topic reports and the Integrated Assessment, the Watershed Nutrient Task Force developed the "Action Plan for Reducing, Mitigating, and Controlling Hypoxia in the Northern Gulf of Mexico" (Action Plan). This called for a 30 percent reduction in MARB nitrogen $(\mathrm{N})$ discharge to the Gulf to reduce the areal extent of Gulf hypoxia from the then most recent 5year running average of $\sim 14000 \mathrm{~km}^{2}$ to a 5-year running average of less than $5000 \mathrm{~km}^{2}$ by 2015 (Mississippi River/ Gulf of Mexico Watershed Nutrient Task Force, 2001).

The process leaves room for improvement with reassessment and the development of a new Action Plan every five years (Mississippi River/Gulf of Mexico Watershed Nutrient Task Force, 2001); however, the deadline has since dropped back to December 2007. At the time of writing, new developments have been in harmony with the conclusions of the six topic reports with increased emphasis on phosphorus (P) as a nutrient of concern in controlling Gulf hypoxia (e.g. Chen et al., 2001; Rabalais et al., 2002a,b; Turner and Rabalais, 2003; Justic et al., 2003a,b, 2005; USEPA, 2004; Osterman et al., 2005; Platon et al., 2005). Also, in 2005, Osterman et al. concluded that since hypoxia occurred temporarily around peak flood years between 1817 and 1910, such lesser transient hypoxic events are natural: at least in the coastal waters sampled between the Mississippi River and Terrebonne estuary (Fig. 2). This, too, is consistent with sediment cores collected earlier to study the history of Gulf hypoxia over the past 200 years (Nelsen et al., 1994; Turner and Rabalais, 1994; Gupta et al., 1996; Rabalais et al., 1999, pp. 93-108) and the official conclusion that natural processes are incapable of producing annually-recurring, regional, seasonal hypoxia (Rabalais et al., 1999). Also new is the Rabalais et al. (2004) study which determined from sediment analysis that there was no shelfwide permanent or sustained hypoxia before the early $1970 \mathrm{~s}$.

Nevertheless, history shows that the scientific method of relentless critical testing of the apparent harmony of scientific consensus leads to the discovery of dissonance. Scientific advancement is made when the dissonance between observation and theory is resolved by improved scientific understanding. In this regard, the observed recurrence of Gulf hypoxia starting with the 1973 flood and the more than doubling of its annual average, starting with the 1993 flood, is not in harmony with measured MARB inputs to the northern Gulf of Mexico. Observations of MARB nutrients $\mathrm{N}$ and $\mathrm{P}$ and freshwater delivery show negligible overall increases since comprehensive nutrient ( $\mathrm{N}$ and $\mathrm{P}$ ) measurements began in the early 1970 s. Furthermore, the proportion of MARB water and nutrients flowing down the Atchafalaya and the Mississippi has stabilised with all of the Atchafalaya MARB water and nutrients and 53 percent of the Mississippi's water reported to contribute to hypoxia (Turner and Rabalais, 1991; Rabalais et al., 1999; Goolsby et al., 1999; CENR, 2000: Kelly et al., 2001).

The hypoxic zone lies within the environs of the Mississippi/Atchafalaya river delta (Fig. 1). River deltas are highly dynamic, flood-sensitive environments, changes in which have profound effects on the physical, chemical, biological and hydrological characteristics of coastal lands and their surrounding waters (Riddell, 1846; Riley, 1937; Fisk, 1952; Gunter, 1952; Bates 1953a,b; Scruton and Moore, 1953; Fisk et al., 1954; Fisk and McFarlan, 1955; Scruton, 1956; 1960; Shepard, 1956; Chew et al., 1962; George, 1972; Van Sickle et al., 1976; Bender et al., 1979; Chabreck, 1972; Ho and Barrett, 1977; Wells, 1980; Wells and Kemp, 1981; Chabreck and Linscombe, 1982; Crout et al., 1984; Cochrane and Kelly, 1986; Dinnel and Wiseman, 1986; Wells and Coleman, 1987; Coleman, 1988; Kesel, 1988; Tyson and Pearson, 1991; Stone et al., 1993; 1997; Day et al., 1995; Stone et al., 1995; Mayer et al., 1998; Anonymous, 1999; Van der Zwaan, 2000).

The nature of the dissonance thus discovered and the relationship of Gulf hypoxia to flooding suggests that serious consideration be given to the hypothesis that coastal changes 


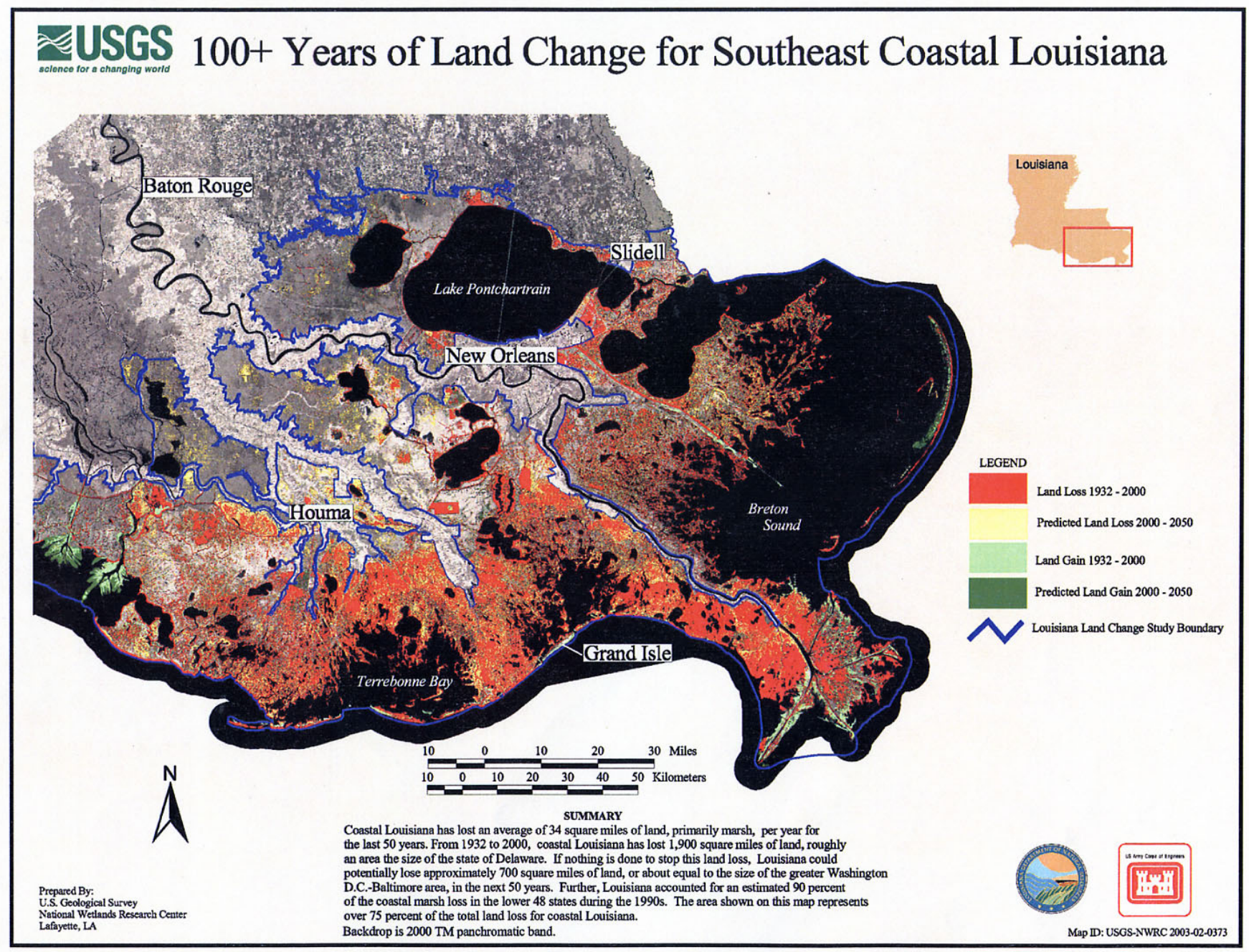

Fig. 2. Land loss and gain in south-east coastal Louisiana (USGS, 2003)

may have a significant effect on hypoxia in the northern Gulf of Mexico.

\section{Method}

The current view is that persistent and growing land-use changes in the MARB are the cause of gradually increasing oxygen stress of the 1800s and early 1900s and the formation of regional, seasonal hypoxia in the second half of the 20th century. However, there are also persistent and growing changes in the coastal environment of the hypoxic zone itself which can result in environmental degradation. The type of coastal change examined here is one that coincides with observations of Gulf hypoxia, namely: the profound regional environmental change that the hypoxic zone is undergoing related to the Atchafalaya's partial capture of the Mississippi River. Such river-switching, delta-building events have occurred here about once every millennium. For the last two centuries, the Atchafalaya's capture of the Mississippi has been growing. During the second half of the 20th century, the effects of this event began peaking and inducing changes greater than that of any coastal environment in the United States and, perhaps, the world.

Analysis of paleooceanographic, geologic and marine research extends temporally and spatially beyond European settlement of the MARB so as to assess whether such change in the coastal environment may be important in the formation of hypoxia.

Finally, this study is followed up by a companion study, "Marine Modification of terrestrial influences on Gulf Hypoxia: Part II" (Krug and Merrifield, 2006). Part II applies a Gulf of Mexico perspective on the hypoxic zone; how the Gulf processes inputs from the Mississippi/Atchafalaya River Basin (MARB) and coastal change, and; the northern Gulf of Mexico's interaction with coastal change. In doing so, Krug and Merrifield (2006) further examine the assumptions used to define the Gulf hypoxia problem. 


\section{Results and discussion}

BACKGROUND

The Mississippi/Atchafalaya River Delta is in the midst of a major river-switching, delta-building event. The 1973 and 1993 floods and Gulf hypoxia are operating in the context of this event. Over the last 200 years, the Atchafalaya's capture of the Mississippi River has been growing, first gradually then explosively. Since the mid-20th century, it may be the world's largest current river capture, the greatest coastal wetland loss and the most massive change in sediment input event (Fisk, 1952; Gunter, 1952; Morgan et al., 1958; Morgan, 1979; Roberts et al., 1980; Chabreck and Linscombe, 1982; Wells and Coleman, 1987; Coleman, 1988; Kesel, 1988; McPhee, 1989; Britsch and Dunbar, 1993; List et al., 1994; Day et al., 1995; Roberts, 1997; Stone et al., 1997; Louisiana Coastal Wetlands Conservation and Restoration Task Force and the Wetlands Conservation and Restoration Authority, 1998; Anonymous, 1999; Bourne, 2000). Indeed, the sediment load of the MARB alone is nearly 20 times the sediment load of all the rivers on the entire East Coast of the USA (Curtis et al., 1973). The effects of this event pervade the hypoxic zone as it is contained by the shoreline principally defined by the Mississippi/Atchafalaya River Delta (Fig. 1) and by its coastal bottom which is principally mud issued from the delta system (Lynch, 1954, p. 80; Thompson, 1955; Shepard, 1956; Van Andel and Poole, 1960; Griffin, 1962; Davies and Moore, 1970; Jones and Williams, 1979; Gunter, 1982; Crout et al., 1984).

Prior to any possible human influence, large rivers and coastal wetland loss created not only persistent coastal hypoxia but also the more severe phenomenon of coastal anoxias with year-round total loss of DO. Marine sediments laid down under such oxygen-depleted conditions later became source rocks for oil and gas from large river deltas draining the MARBs of the geologic past (e.g. Zangerl and Richardson, 1963; Hallam, 1967; Rainwater, 1972; Jenkyns, 1980; Picou, 1981; Pratt, 1984; Wenger and Baker, 1986; Wenger et al., 1988; Fails, 1990; Leckie et al., 1990; Coveney et al., 1991; Heckel, 1991; Oschmann, 1991; Tyson and Pearson, 1991; Hatch and Leventhal, 1992; Schultz and Coveney, 1992; Hay, 1995; Isaksen, 1995; Mello et al., 1995; Olszewski, 1996; Genger and Sethi, 1998; Hoffman et al., 1998; Holmden et al., 1998; Van der Zwaan, 2000; Wignall and Newton, 2001).

The scientific literature recognises that such potentially oil-forming events have been occurring in the coastal waters of the modern Mississippi/Atchafalaya River Delta by riverswitching, delta-building events since the last Ice Age when sea level reached approximately its present level (Lowman,
1951; Rainwater, 1972; Levin, 1991; Kosters and Suter, 1993; Kosters et al., 2000, 2002). For example, analysis of marine sediments deposited over the last 4600 years in the eastern half of the hypoxic zone indicate alternating periods of land loss (marine transgressions) and land gain (marine regressions) with alternating periods of persistent anoxic and oxic coastal waters (Levin, 1991). Nevertheless, whereas such river-delta switching can naturally produce even persistent coastal ocean anoxia, only the Topic 1 Report (Rabalais et al., 1999) deals with even some of its relevant elements. The Topic 1 Report's curt treatment of sediment input and wetland loss states that input of MARB sediment and input from coastal wetland losses cannot account for Gulf hypoxia (Rabalais et al., 1999, pp. 59-60) and the effects of river-delta switching are not mentioned at all by Boesch (1999) or the Integrated Assessment (CENR, 2000). And, as discussed earlier, subsequent publications agree with the conclusion that non-MARB changes (with the possible exception of secondary effects induced by climate change) cannot produce annually-recurring, seasonal Gulf hypoxia.

\section{LAND LOSS (MARINE TRANSGRESSION)}

Hundreds-to-thousands of years of stored nutrients and organic matter are bleeding into the hypoxic zone from the massive wetland loss: 80 percent of tidal wetland loss for the entire continental USA occurs in the Mississippi/ Atchafalaya River Delta (Roberts, 1994).

From the time of the earliest reviewed and published documentation in the 1800 s, land loss had been occurring along the hypoxic zone (Gunter, 1949, 1952; Mackin and Hopkins, 1961; Allen et al., 1984). During the 20th century the rate of Mississippi/Atchafalaya River Delta land loss has increased from $17 \mathrm{~km}^{2} \mathrm{yr}^{-1}$ in 1914 to an average of $65.7 \mathrm{~km}^{2} \mathrm{yr}^{-1}$ for 1983 to 1990 . Historically, most wetland loss occurred along the eastern half of the hypoxic zone: between the Mississippi and Atchafalaya Rivers rather than from the more sand-rich marginal delta Chenier plain to the west of the Atchafalaya (Morgan, 1977; Wells and Coleman, 1987; Britsch and Dunbar, 1993; Fig. 1). A map (Fig. 2) showing the massive land loss and projected future loss along the eastern half of the hypoxic zone has been prepared by the US Geologic Survey (USGS, 2003).

This land loss is accompanied by increases in the area and depth of open inland water, destruction of barrier islands across the mouths of these enlarging estuaries and bays, and widening and deepening of the channels that connect the hypoxic zone to the enlarging bays and estuaries. All of these changes act in concert to increase erosion capacity and the transfer of water and material from the degrading delta to the hypoxic zone. With the increasing size of these 
inland waters comes increasing fetch, increasing wave size and energy. With this comes increasing physical erosion potential: more energy to erode soil and sediment from the shores and bottoms of the growing inland waters (Gunter, 1952; Thompson, 1955; Smith and Sinclair, 1972; Jonasson and Lindegaard,1979; Tanner, 1982; Perret and Chatry, 1988; Sparks et al., 1990; Nerem et al., 1998). Enhancing physical erosion potential and concomitant increase of inland water volume is accompanied by increasing amount and efficiency of water and material transmission from the degrading delta region to coastal waters where regional coastal hypoxia now occurs (Gunter, 1952; Thompson, 1955; Van Sickle et al., 1976; Penland and Boyd, 1985; Perret and Chatry, 1988; Levin, 1993, List et al., 1994; Reed et al., 1995; Roberts, 1997).

Increasing amount and efficiency of transmission of water and material between the Gulf and inland waters also increases the amount of saltwater introduced by tides into the inland waters. The increase in saltwater induces ecological changes which include increased chemical erosion of delta soils and sediment. Organic matter is a major constituent of the delta's wetland soils (Table 1). The buildup of wetland organic matter results from incomplete oxidation of the prodigious amounts of organic matter produced by the wetlands themselves: wetland organic matter production exceeds the rate that oxygen can be supplied to decompose it, especially in freshwaters (Wetzel, 1979; Wetzel, 1983). Unlike freshwater, however, the highest concentrations of biologically-usable oxygen (O) in seawater available to decompose soils and sediments is not that of oxygen gas $\left(\mathrm{O}_{2}\right)$ : the highest concentrations are as $\mathrm{SO}_{4}-\mathrm{O}$. Whereas concentrations of $\mathrm{O}_{2}$ are generally less than $10 \mathrm{mg} \mathrm{O}_{2}-\mathrm{O} \mathrm{L}^{-1}$, in average seawater there is $1770 \mathrm{mg}$ $\mathrm{SO}_{4}-\mathrm{O} \mathrm{L}^{-1}$ so that even slight additions of seawater markedly increase the sulphate linked decomposition of organic matter (Capone and Kiene, 1988; Gardner et al., 1991; Jackson et al., 1995).

The overall effect of saltwater intrusion is that the more saline the water, the less organic matter can accumulate in

Table 1. Percentage of organic matter and N content of Mississippi Delta marsh soils by vegetation type. (Calculated from soils dry weight data of Chabreck, 1972)

\begin{tabular}{lcll}
\hline & $\begin{array}{l}\text { Salt } \\
\text { Marsh }\end{array}$ & $\begin{array}{l}\text { Brackish } \\
\text { Marsh }\end{array}$ & $\begin{array}{l}\text { Freshwater } \\
\text { Marsh }\end{array}$ \\
\hline Organic Matter & 13.18 & 30.84 & 40.16 \\
Nitrogen & 0.44 & 1.07 & 1.41 \\
\hline
\end{tabular}

wetland soils and sediments bordering the hypoxic zone (Table 1) and less wetland soil laid down. Thus, wetlands are more prone to become open waters as they are unable to accumulate enough soil to offset erosive forces which are increasing. Increases in saltwater intrusion result in the physicochemical erosion of delta soils and sediments and enhanced release of nutrients and transfer of water and material from the degrading delta to the hypoxic zone.

Saltwater intrusion was a problem in the 1800 s when the waters of lower Barataria Bay and other nearby inland waters had already become too saline for natural oyster reproduction (Allen et al., 1984, p. 90). Under Spanish rule in the second half of the 18th century, oysters became an important food source for New Orleans; a road was built to Barataria Bay and all oysters came from natural oyster reef production. But by 1870 artificial oyster production practices were widely and extensively used due to the already far advanced deterioration of the oyster reefs (Gunter, 1949; Mackin and Hopkins, 1961; Allen et al., 1984). Increasing salinity in the Barataria Bay estuary continued to exacerbate oyster production problems into the second half of the 20th century (Van Sickle et al., 1976).

Estuaries can export considerable quantities of oxygenconsuming organic carbon and associated nutrients to coastal waters (Odum, 1971, pp. 352-361; Happ et al., 1977; Madden et al., 1988; Odum, 2000). Given that estuaries and associated wetlands are known for their exceedingly high rates of primary productivity (Odum, 1971; Happ et al., 1977; White et al., 1978; Wetzel, 1979), organic carbon outputs from coastal estuaries and wetlands may also have a significant effect on hypoxia.

Data from Barataria Bay can be used to indicate the quantity of oxygen-consuming material bleeding into the hypoxic zone from these enlarging inland waters. During the 1970 s, about 30 percent of the total net above-ground primary production was flushed out into the hypoxic zone annually (Day et al., 1973; Happ et al., 1977; Feijtel et al., 1985; Madden et al., 1988). Primary productivity in the hypoxic zone is reported to be high, $122 \mathrm{~g} \mathrm{C} \mathrm{m}^{-2} \mathrm{yr}^{-1}$ (Justic et al., 1997). In contrast, planktonic primary productivity in the Barataria Bay estuary, excluding benthic production inherent in these shallow estuarine waters, produces $450 \mathrm{~g}$ $\mathrm{C} \mathrm{m}^{-2} \mathrm{yr}^{-1}$ (Happ et al., 1977). An additional $240 \mathrm{~g} \mathrm{C} \mathrm{m}^{-2} \mathrm{yr}^{-1}$, conservatively, is estimated to be flushed into the estuary from its surrounding marshes (Happ et al., 1977). Hence, the export of organic carbon from the $1800 \mathrm{~km}^{2}$ of inland water in the $6300 \mathrm{~km}^{2}$ Barataria basin was between 140 and $190 \mathrm{~g} \mathrm{C} \mathrm{m}^{-2} \mathrm{yr}^{-1}$, i.e. 210000 to 280000 metric tons $\mathrm{C} \mathrm{yr}^{-1}$ during 1972 and 1973. Like the marsh export figures, these estuarine export figures are conservative; field measurements of organic carbon export to the coastal ocean 
were taken during calm weather and not during storms and rough weather when disproportionately large amounts of organic carbon are moved (Happ et al., 1977). Furthermore, rates of primary productivity of these delta estuaries are reported to be increasing after the above studies were made (National Oceanic and Atmospheric Administration, 1997).

Using information on the average area and productivity of the 1985-1992 hypoxic zone (Justic et al., 1997; Rabalais et al., 1999), the export of organic carbon in the Barataria outflow is assessed to be equivalent to 22 to 29 percent of the hypoxic zone's total annual net primary productivity. Nitrogen, a macronutrient of this exported algae and wetland plant organic matter, is reported to boost Gulf productivity about four times through recycling (Turner and Rabalais, 1991; Rabalais et al., 1999, p. 87). If this is so, then organic loading imposed by the Barataria's outflow alone exerted an oxygen demand on Gulf coastal waters about equal to that of the hypoxic zone's total average annual 1985-1992 net primary productivity. Recycling is a reasonable assumption for coastal waters in that the world's coastal waters are heterotrophic, i.e. even the high input of terrestrial carbon to coastal waters is nearly completely decomposed to $\mathrm{CO}_{2}$, making net respiration greater than net primary production (Berner, 1982; Smith and Mackenzie, 1987). In regard to recycling in Louisiana's coastal waters, the organic carbon concentration of MARB river sediment averages 2.28 percent (Malcolm and Durhum, 1976) whereas surficial sediments sampled from shallow waters of the nearby inner continental shelf average about 0.6 percent (Gupta et al., 1996) in spite of the C enrichment from dead algae, wetland plant organic matter and eroded organic-rich delta mucks and peat. These sediment values indicate that recycling is at least four-fold.

The Barataria estuary represented about 10 percent of Louisiana's total area of estuary in the 1970s (Farrell, 1979) and occupied about 10 percent of the coastline bordering the hypoxic zone. The Barataria-Terrebonne National Estuary Program reports that during the 1970s the daily tidal flush of estuarine water from Barataria into the hypoxic zone was estimated as averaging 230 million $\mathrm{m}^{3}$ day $^{-1}$ (Swenson and Swarzenski, 1995). The Barataria and Terrebonne estuaries occupy about 30 percent of the coastline bordering the hypoxic zone. The daily tidal flushing of water from the Barataria and Terrebonne estuaries into the hypoxic zone averaged about 750 million $\mathrm{m}^{3}$ (Swenson and Swarzenski, 1995). Thus, the combined oxygen demand imposed by these estuarine outflows may be greater than that imposed by the hypoxic zone's total average annual 1985-1992 net primary productivity.

Whereas MARB water and nutrient input have increased negligibly since the early 1970 s, drastic changes are occurring in the estuaries bounding the hypoxic zone. Since the 1972-73 study of Happ et al. (1977), land loss continued at a high rate; by 1988 the area of open water in the Barataria Basin grew to $2952 \mathrm{~km}^{2}$ (47 percent). If nothing is done, 67 percent of Barataria Basin is projected to be open water by 2018. This appears to be typical of what is happening in the marine transgression (eastern) half of the hypoxic zone (Martin et al., 2000). With this marine transgression comes ever more erosion and ever increasing transfer of water and material from the degrading delta to the hypoxic zone, marine transgression processes that naturally contribute to oxygen depletion of coastal waters.

The escalating volume of freshened and warmed estuarine water being flushed daily into the hypoxic zone changes coastal hydrology by strengthening summertime stratification. Strengthening stratification combined with the outflow of hundreds-to-thousands of years of accumulated oxygen-consuming nutrients and organic matter, and highly productive estuarine water, all act in concert increasingly to promote hypoxia as marine transgression progresses along the disintegrating coastal lands of the eastern half of the hypoxic zone.

The effects of marine transgression on Gulf hypoxia have yet to be researched and quantified.

\section{ATCHAFALAYA RIVER LAND GAIN (MARINE REGRESSION)}

As discussed earlier, the amounts and proportion of MARB water and nutrients flowing down the Atchafalaya and the Mississippi are recognised as having stabilised since the early 1970s. However, the Atchafalaya's influence on the hypoxic zone has yet to stabilise. With the great flood of 1973, the Atchafalaya mud stream achieved breakthrough to the coast and altered the coastal dynamics of the hypoxic zone permanently (Roberts et al. 1980; Wells 1980; Wells and Kemp, 1981, 1982; Roberts, 1998; Huh et al., 2001; Draut et al., 2005).

By 1973 the Atchafalaya River had already become a mighty river, the average flow of which was four times greater than that of the Nile (Wright and Coleman, 1973). But, there was still memory of it having been a much smaller river: "The writer once talked to an old Creole gentleman of that region who drove cattle across the Atchafalaya at a 'ford' during low water stages approximately 85 years ago" (Gunter, 1952, p. 125).

Earlier than that, the Atchafalaya was not even considered to be a river. Between the time it was first mapped in 1542 and a subsequent map in 1769, the Atchafalaya was shown as being just one of the Mississippi's many bayous (Humphreys and Abbot, 1876; Fisk, 1952; Shlemon, 1972; 
Meade, 1995; McPhee, 1989). In 1778, the Atchafalaya was finally mapped as being a river - a river whose mouth on the Mississippi was deep enough to float logs (Bringier, 1821; Humphreys and Abbot, 1876, p. 460; Fisk, 1952, p. 17). The rate of river capture was comparatively modest through the 1800s, but growth was rapid in the 20th century (Gunter, 1952). The floods of 1927, 1973 and 1993 are notable for accelerating the Atchafalaya River's capture of water and sediment from the Mississippi and the transfer of this water and sediment into the heart of the hypoxic zone (Fig. 1).

The 1927 flood, the greatest recorded in the lower Mississippi, markedly accelerated the transfer of water and sediment from the Mississippi to the Atchafalaya (Gunter, 1952) but the increase in sediment transport down the Atchafalaya to the Gulf lagged behind the increase in water. Much of the vast lake/wetland/lowland system along the Atchafalaya had to be filled by sediment before appreciable sediment could be transported to the coast. The 1927 flood initiated rapid filling of the Grand Lake system through which the Atchafalaya flows. Between 1930 and 1950, the Atchafalaya had filled in over $160 \mathrm{~km}^{2}$ of the Grand Lake system. By the $1950 \mathrm{~s}$, sufficient fine sediments were discharging to the coast of the hypoxic zone to form noticeable mud deposits (Fisk, 1952; Bates, 1953a; Morgan et al., 1958): "The bathymetry of Atchafalaya Bay changed very little from an 1858 survey until the obvious influx of sediments began in the early 1950s" (Roberts et al., 1980, p. 266).

By 1950, the Atchafalaya River had captured 30 percent of the flow of the Mississippi and was projected to complete its capture of the Mississippi during the 1970s (Fisk, 1952). In 1963, the US Army Corps of Engineers stabilised the Atchafalaya at its 1950 flow rate of about 600 million $\mathrm{m}^{3}$ day $^{-1}$ with a control structure (McBrayer, 2004; U.S. Army Corps of Engineers, 2004). However, this did not stabilise the sediment load delivered down the Atchafalaya. Lakes and backwaters along the Atchafalaya were still retaining much of the river's sediment load, and stopping a large proportion of the sediment from reaching the coast. As these inland sediment sinks continued to fill up, more and more of the Atchafalaya's sediment load got passed through: "The growth of mudflats will be accelerated as the capacity of the Atchafalaya channel to carry load develops. During the critical and final stages of diversion, coarse load should be introduced for the first time into Atchafalaya Bay" (Fisk, 1952, pp. 139).

During the 1950s and 1960s, clays and silts built a submarine delta across Atchafalaya Bay to near the reefs which separate Atchafalaya Bay from the waters of the hypoxic zone. By 1972 coarse load had yet to pass through the Atchafalaya River to reach Atchafalaya Bay (Roberts et al., 1980). Then came the 1973 flood! Regional hypoxia then began to be noticed in the northern Gulf of Mexico. People have regularly and heavily fished the region and environmental monitoring was going on mainly in connection with the thousands of oil rigs (Sharp and Appan, 1978; Bender et al., 1979; Oetking et al., 1979a; National Research Council, 1983). Nevertheless, it was research associated with offshore oil rig monitoring that found hypoxia to be widespread under the freshwater cap produced by the 1973 flood (Bender et al., 1979; Oetking et al., 1979a). Thereafter, a seasonal, apparently regional, hypoxia has been an essentially yearly phenomenon (Ragan et al., 1978; Bender et al., 1979; Oetking et al., 1979a,b; Bedinger et al., 1981; Harper et al., 1981; Rossignol-Strick, 1985). This was observed even before the shipboard synoptic monitoring initiated in 1985 (Rabalais et al., 1991) by scientists who later became involved in the hypoxia assessment.

It was during the 1973 flood that the Atchafalaya almost became the new main-stem of the Mississippi. Although suffering major damage, the US Army Corps of Engineers' control structure held (McPhee, 1989; McBrayer, 2004). Even though the Atchafalaya did not become the main-stem of the Mississippi, the effects of the 1973 flood were significant. Fisk's (1952) prediction about the future introduction of coarse sediment load into Atchafalaya Bay came true; the Atchafalaya had finally achieved breakthrough, with significant amounts of coarse load, sandsized material, entering Atchafalaya Bay. With the 1973 flood, total sediment load to Atchafalaya Bay jumped from 57 million metric tonnes per year (of which 52 million metric tonnes were silt plus clay) to 112 million metric tonnes per year (of which 81 million metric tonnes were silt plus clay) (Roberts et al., 1980). Converted to volume (Wells and Kemp, 1981), the annual volume of sediment discharged to Atchafalaya Bay was over 200 million $\mathrm{yd}^{3} \mathrm{yr}^{-1}$, equivalent to the amount of earth moved to create the Panama Canal.

Now it was Atchchafalaya Bay's turn to fill in earnest. As more than $500 \mathrm{~km}^{2}$ of the bay filled up, river sediment would be transferred more efficiently through the bay and into the hypoxic zone (Shlemon, 1972). Previously, a quarter of the sediment delivered by the Atchafalaya River to Atchafalaya Bay passed through the bay into the open Gulf. After the 1973 flood, this fraction jumped to 50 percent (Fisk, 1952, pp. 139; Wells and Kemp, 1981).

Prior to 1973, net land loss was occurring in Atchafalaya Bay and the coast west of it: the coast bordering the western half of the hypoxic zone (Fig. 1). Unlike the wetlands bordering the eastern half of the hypoxic zone, the Chenier Plain, which occupies most of the coast west of Atchafalaya 
Bay, has a series of protective sand ridges. Also, the rate of land subsidence is less than that closer to the Mississippi River. The amount of land being lost from the Chenier Plain was lower than the wetland loss of the eastern half (Morgan and Larimore, 1957; Wells and Kemp, 1981; 1982; Chabreck and Linscombe, 1982; Otvos and Price, 1982; Sonnenfeld, 1983). Nor is the nutrient and organic content of sand anywhere as great as that of mud, let alone that of the disintegrating wetland peats and mucks of the east (Wakesman and Hotchkiss, 1937; Hickel et al., 1989; Table 1).

Starting in 1973, the coastline west of Atchafalaya Bay, Atchafalaya Bay itself and the estuaries immediately to the east of the bay, were reported as having begun a net gaining of land, reversing their previous trends of land loss. The increase in the amount of Atchafalaya River mud passing through Atchafalaya Bay into open coastal waters was great enough to reverse land loss and to start building land, in spite of the erosive forces of wave, wind, current, tide and storm on the fluid muds of the Atchafalaya mud stream (Wright, 1977; Roberts et al., 1980; Van Heerden et al., 1981; Wells and Kemp, 1981; Madden et al., 1988; Roberts, 1997).

Thus two things happened with the 1973 flood that increased the discharge of nutrient- and organic-rich mud to the open bay: increased discharge of sediment to Atchafalaya Bay plus increased efficiency of sediment transfer through the bay to the open Gulf.

Mud and water discharged by the Atchafalaya are more efficient in depleting oxygen than water and sediment discharged by the Mississippi River. The Atchafalaya discharges its freshwater and fertile mud into the inshore middle of the hypoxic zone. On the other hand, the Mississippi River extends across the continental shelf on which hypoxia forms and discharges its water and sediment beyond the far edge of where hypoxia forms (Fig. 1). Discharge of water and sediment here results in loss of water and most sediment beyond the hypoxic zone (Riddell, 1846; Humphreys and Abbott, 1876; Bates, 1953b; Fisk, 1952; Fisk et al., 1954; Fisk and McFarlan, 1955; Scruton, 1956; Wennekens, 1959; Shlemon, 1972, p. 37; Gagliano et al., 1973; Maul, 1974; Atkinson and Wallace, 1975; Rouse and Coleman, 1976; Crout et al., 1984; Lindsay et al., 1984; Sturges, 1993; Dowgiallo, 1994; Ortner et al., 1995; Li et al., 1997; Cho et al, 1998; Conkright et al., 1999; He and Weisberg, 2002; Welsh and Inoue, 2002; Morey et al., 2003a,b; Weatherly et al., 2003; US Army Corps of Engineers, 2004). To quote the USGS, there is a profound difference in the processing of sediment and water discharged to the Gulf by the Mississippi and Atchafalaya Rivers: "This differential processing is primarily due to the discharge of Atchafalaya River waters into a broad, shallow inner shelf environment, while Mississippi River waters discharge into the Gulf of Mexico, beyond the shelf break" (Swarzenski, 2001, p. 2).

Bathymetry dating back to the 1700 s shows that the modern Mississippi River (Birdfoot) delta has been building itself across deep water rather than the continental shelf (US Coast Survey, 1861; Humphreys and Abbott, 1876, pp. 472 473, Plate 2; Hilgard, 1906). This distinguishes the current version of the Mississippi River from the Atchafalaya and the previous anoxic events in which river-switching events started out by discharging on the inshore side of the continental shelf: "Since the sea reached its present level, the Mississippi River has occupied and abandoned several courses on the alluvial plain, including the Maringouin, Teche, Lafourche, and LaLoutre..... Each of the pre-modern deltas was built seaward in shallow marine waters across fine-grained deposits of the topstratum and developed narrow deep distributaries. The birdfoot delta, which is developing in deep waters at the edge of the continental shelf, is in marked contrast to the older deltas on the plain" (Fisk and McFarlan, 1954, p. 33).

Were it not for the intervention of the US Army Corps of Engineers in preventing the Atchafalaya River from becoming the new main-stem of the Mississippi River, the northern Gulf of Mexico might now be experiencing yearround anoxia, as was experienced with the Atchafalaya analogues of the past, prior to human intervention, rather than just seasonal hypoxia.

As with the influx of wetland soil, plant materials and nutrients from the disintegrating coastal lands of the east, the massive increase of Atchafalaya River sediment starting in 1973 increased oxygen demand in the hypoxic zone through the influx of organic matter and nutrients (Ellis, 1931; Wakesman and Hotchkiss, 1937; Fair et al., 1941; Loesch, 1960; George, 1972; Anikouchine and Sternberg. 1973, p. 262; May, 1973; Rowe et al., 1975; Martens et al., 1978; Berner, 1982; Wahby and Bishara, 1982; Stora and Arnoux, 1983; Smith and Mackenzie. 1987; Hickel et al., 1989; Cooper and Brush, 1991; Yang et al., 1998). Furthermore, research shows that decomposition of sediment organic matter, release and recycling of sediment nutrients is enhanced by the environmental conditions existing in the coastal waters off the Atchafalaya River. The erosive forces of normal wave, wind, current, and tide on the shallow waters of this continental shelf, in addition to some 30 cyclonic storm events per year (e.g. Pepper et al., 1999), turn the fluid muds of the Atchafalaya mud stream and loose bottom muds into fluidised reactor beds where carbon and nutrients are decomposed and released and recycled over and over again (Trefry et al., 1994; Aller, 1998; Abril et al., 
1999, 2004; Rowe et al., 2002; Gordon and Goni, 2003; Aller et al., 2004; Aller and Blair, 2004; Corbett et al., 2004; McKee et al., 2004; Sutula et al., 2004): "Fluid muds and mobile surface material cause the seafloor and continental boundary to act as a massive, suboxic, fluidised bed reactor... Reoxidation, repetitive redox successions, metabolite exchange, and continual mixing-in of fresh planktonic debris with refractory terrestrial components, results in an effective decomposition system largely decoupled from net accumulation" (Aller, 1998, p. 143).

It is thus that the regional anoxias of the past can be explained. And, in combination with anthropogenic influences in the MARB and possibly elsewhere, the regional hypoxia of the present can be explained.

The Atchafalaya sediment problem did not stabilise after the 1973 flood; it continued to grow. The proportion of total sediment load of the Atchafalaya was increasing relative to that of the Mississippi; and the efficiency of the Atchafalaya in transporting this sediment to the coast was increasing as lowlands and backwaters along its path continued to fill (Fremling et al., 1989; Mossa, 1989; 1991).

After 1973, Atchafalaya Bay continued to fill (Wells, 1980; Wells and Kemp, 1981) with the above-water portion of the Atchafalaya's outlets reported to be growing seaward across the bay at $400 \mathrm{~m} \mathrm{yr}^{-1}$ (Roberts, 1997). Assuming that the control structure continues to hold out, it was estimated that it would take about 70 years (2040) after the 1973 flood for Atchafalaya Bay to be effectively filled. It was also reported that major floods would accelerate the bay-filling process. For example, in another 1973-like flood, the bay would fill in about 10 years, in other words, the efficiency of sediment transfer to the hypoxic zone would be further enhanced and accelerated to approach 100 percent sediment transfer efficiency to the Gulf (Adams and Baumann, 1980; Roberts et al., 1980; Donnell and Letter, 1992).

Another major flood in 1993 materially affected the environment and increased the delivery of river water and mud to offshore coastal waters (e.g. Roberts, 1998; Anonymous, 1999). After the 1993 flood, the average size of the hypoxic zone increased remarkably. The discharge of water and sediment act in concert to promote hypoxia as Atchafalaya-based marine regression and bottom mud deposits develop in and along the hypoxic zone: marine regression processes contribute naturally to oxygen depletion of coastal waters.

The effects of marine regression on Gulf hypoxia have yet to be researched and quantified.

\section{Conclusions}

The CENR approach to Gulf hypoxia emphasises the input of nutrient-rich water from the MARB as the cause of hypoxia and as the means of its control. A Watershed Nutrient Task Force was formed to solve the hypoxia problem by managing the MARB watershed. But MARB water and nutrient input have increased negligibly since comprehensive measurements were first made in the early 1970s while Gulf hypoxia and the Gulf environment have changed markedly. The Gulf environment is undergoing massive physical, hydrological, chemical and biological changes accompanying marine transgression and regression associated with the current river-switching, delta-building event. Since such coastal environmental change is capable of inducing even persistent anoxia and has done so prior to European settlement of the MARB, Gulf hypoxia was analysed in this context.

Regarding changes associated with the current riverswitching event, that part of the delta partially abandoned by the Mississippi River is undergoing enormous land lossmarine transgression. About 80 percent of all tidal wetland land loss from the continental USA is occurring here. As these wetlands disintegrate, the hundreds-to-thousands of years of accumulated oxygen-consuming nutrients and organic matter stored in them are released to be flushed out into the hypoxic zone. On the basis of the nutrient recycling method used to calculate the effect of MARB runoff on net primary productivity in Gulf coastal waters, the 230 million $\mathrm{m}^{3}$ day ${ }^{-1}$ outflow from the Barataria estuary is assumed to exert an oxygen demand equal to that of the hypoxic zone's total average annual primary productivity. The combined estimated daily flush of 750 million $\mathrm{m}^{3}$ from just the Barataria and Terrebonne estuaries may impose an oxygen demand even greater than that of the hypoxic zone's own primary productivity.

If marine transgression is allowed to progress in and along the eastern half of the hypoxic zone, its influence on the hypoxic zone will grow. Wetlands will continue to disintegrate, inland waters will continue to enlarge, and the coastal barriers separating these exceptionally-productive estuarine waters from the hypoxic zone will continue to disintegrate. Increasingly, hypoxia-favourable hydrology induced by escalating volumes of freshened and warmed estuarine water, combined with the outflow from hundredsto-thousands of years of accumulated oxygen-consuming nutrients and organic matter, and highly productive estuarine water, all act increasingly to promote hypoxia as marine transgression progresses along the disintegrating coastal lands of the eastern half of the hypoxic zone.

Since the early 1970s, there also has been an increasing influence of the Atchafalaya River on the hypoxic zone. With the great flood of 1973, the Atchafalaya mud stream broke through to the coast and marine regression and 
alteration of coastal dynamics along the hypoxic zone were initiated. With the 1993 flood, the efficiency of sediment transmission down the Atchafalaya River increased further as did the efficiency of sediment transmission from Atchafalaya Bay to the Gulf. The two-stepped increase in mud corresponds to the two discussed seminal observations of Gulf hypoxia.

The great amounts of wetland loss along the eastern half of the hypoxic zone (accompanying the Mississippi River's partial abandonment), and the initiation of marine regression in and along the central and western half of the hypoxic zone (accompanying the Atchafalaya's partial capture of the Mississippi) and associated hydrological changes, act in concert to facilitate oxygen depletion in the hypoxic zone.

Historical studies of the type presented here should be viewed as a benchmark tool for environmental research and management for critical issues of the evolution of the southern US rivers and the Gulf of Mexico. Such historybased studies provide a context for the present and an example of what has happened in the past and their value extends far beyond that of the case in hand presented here. It is recommended that a truly holistic environmental approach to understanding the causes and controls of the Gulf of Mexico be adopted including, but not limited to, MARB inputs and coastal change.

\section{References}

These are listed at the end of the companion paper, pages 199209.

\section{Appendix I}

The distribution of green, yellow, brown and blue colours are informative of what is happening in this 08 January 2002 view of the northern Gulf of Mexico. Deep blue is indicative of clear Gulf water. Blues with milky casts are consistent with the presence of coccolith algae (whose carbonate shells make chalk); the line of milky blue waters across the bottom of the image represent the strong eastward movement of the Gulf's Boundary Current. The Boundary Current interacts dynamically with shelf water, Atchafalaya River water and Mississippi River water - as indicated by the distribution of yellow and brown sediment-laden water and green algae water. Much water from the Atchafalaya River and its nearby shelf area is moved offshore and east toward the Mississippi River Delta. Water issuing from the Mississippi's southwest outlet becomes blocked from further westward movement; water issuing from other Mississippi River outlets moves in different directions. Outflow is seen from the estuaries between the Mississippi and Atchafalaya. The Atchafalaya empties into a bay from whose westernmost part muddy outflow moves west along the coast as the Louisiana Coastal Current to rivers near the Texas coast, the rivers showing offshore flow.

Additional supporting satellite imagery for this day can be accessed through the Space Science and Engineering Center website: http://eosdb.ssec.wisc.edu/modisdirect/ historical/. Higher resolution sea surface temperature and turbidity satellite images of the Mississippi River Delta and the area of the Atchafalaya River for this day can be accessed on the Louisiana State University's Earth Scan Laboratory website: http://www.esl.lsu.edu/research/NOAA_AVHRR/ archive_baywatch.php?day 